\title{
Calcium from limestone meal and grit in laying hen diets - effect on performance, eggshell and bone quality $^{*}$
}

\author{
J. Koreleski ${ }^{1}$ and S. Świątkiewicz \\ National Research Institute of Animal Production, \\ Department of Animal Nutrition \\ 32-083 Balice, Poland
}

(Received 11 May 2004; accepted 25 October 2004)

\begin{abstract}
Limestone was crumbled into fine particles (LF) of 0.1-0.4 mm or to a particulate grit (LG) of 2-4 mm. One hundred and eighty individually kept Hy-Line Brown laying hens were used in the experiment and divided into 10 groups. Diets containing $8.1 \%$ of LF or LG substituted for LF at a proportion of $10,20,40,50,60,80$ and $100 \%$ were compared with diet containing $8.1 \%$ oyster shells.

At moderate substitution levels, the particulate limestone grit increased the thickness of eggshells in the first laying period $(60-80 \%$ LG), improved yolk pigmentation $(20-100 \%$ LG) and enlarged calcium deposition in eggshells (10-100\% LG). Partial (20-90\%) and complete substitution of LG for LF increased eggshell breaking strength, but improvement of tibia bone strength was observed only at $20 \%$ LG limestone. Analysis of feed refusals suggests that the limit value of voluntary intake of grit particles LG is $5.5 \mathrm{~g}$ daily per hen.
\end{abstract}

KEY WORDS: limestone meal, limestone grit, laying hens, eggshell quality, tibia bone, breaking strength

\section{INTRODUCTION}

Pulverized and grit forms of limestone and oyster shells are used as calcium supplements for laying hens. The solubility of finely ground limestone has no effect on calcium utilization (Cheng and Coon, 1990; Richter et al., 1999). Particle-sized

\footnotetext{
* Supported by the State Committee for Scientific Research, Grant No. 6 P06Z 01421

${ }^{1}$ Corresponding author: e-mail: jerzy.koreleski@izoo.krakow.pl
} 
calcium sources persist in the gizzard and tend to cover calcium requirements of hens better than pulverized sources (Scott et al., 1971; Roland and Harms, 1973; Guinotte and Nys, 1991; Richter et al., 1999). The slower dissolution of grit forms may make calcium available during the night, when there is no feed intake but calcification of eggshells is proceeding (Roland and Harms, 1973). It may minimize the mobilization of bone calcium (and phosphorus) reserve, processes that can negatively affect eggshell quality (Farmer et al., 1986).

The purpose of this study was to determine the optimal proportions of both fine and particulate grit limestone in hen diets for maximum laying performance, eggshell quality and tibia bone strength.

\section{MATERIAL AND METHODS}

Sedimentary ledges of compact organic-origin limestone of proper purity and high calcium content were used. Limestone was mined from Lower Carbon layers and contained, $\%: \mathrm{CaCO}_{3}, 95 ; \mathrm{MgCO}_{3}, 1.2 ; \mathrm{SiO}_{2}, 1.5$, and was of feeding purity grade. The limestone was crumbled to fine particles of $0.1-0.4 \mathrm{~mm}$ (LF) or to particulate grit of 2-4 $\mathrm{mm}(\mathrm{LG})$ in square sieve size.

Hy-Line Brown laying hens aged 25 weeks were used in the experiment that started in May 2002. During rearing the birds were fed and managed according to guidelines for Hy-Line chickens. The hens were divided into 10 groups, each of 18 hens kept in individual cages on a wire mesh floor under a 14L:10D lighting schedule with the dark period at night. During 47 weeks of the experiment (up to 72 weeks of age), the hens had free access to mash feed and water. The cereal-soyabean meal-based diet (Table 1) contained $8.1 \%$ of LF (control group) and in groups II-IX, LG was substituted for a portion of LF at a rate of $10,20,40,50,60,80,90$ and $100 \%$ (Table 2). For comparison $100 \%$ oyster shell substitution of LF was also used (group X). Feed intake, number and mass of eggs laid were noted. For shell percentage, thickness and density, and for yolk colour assessment one egg per hen was collected at 33, 48 and 72 weeks of age. Egg Quality Measurement (Micro version 3.2, 1990) for egg quality evaluation was used. In the morning (after the dark period) one uncracked egg was collected from each hen at the start of week 33, 48, 53, 63, 68 and 72 of age. Shell breaking strength $(\mathrm{N})$ using an Instron equipment, (Table Model Number 5542) was tested on eggs from pole to pole. Remainders of feed in feeders were collected at 7-day intervals during the last 4 weeks of the experiment and an average sample was prepared and separated on a square sieve $\Phi 1.5$ and $2 \mathrm{~mm}$. The LG fraction ( $>2 \mathrm{~mm}$ ) was separated and cleaned from the feed, weighed and its percentage level in total feed refusals was calculated. At the end of the experiment, 4 hens from each group were decapitated, the tibia 
TABLE 1

Composition of basal diet, $\mathrm{g} \mathrm{kg}^{-1}$

\begin{tabular}{lc}
\hline Item & Content \\
\hline Maize & 330.0 \\
Wheat & 260.7 \\
Soyabean meal & 192.0 \\
Rapeseed meal & 40.0 \\
Grass meal & 30.0 \\
Blended fat & 30.0 \\
Rapeseed oil & 10.0 \\
Limestone & 81.0 \\
Dicalcium phosphate & 17.0 \\
NaCl & 3.0 \\
DL-methionine & 1.1 \\
L-Lysine & 0.2 \\
Vitamin-mineral premix ${ }^{1}$ & 5.0 \\
Analysed & \\
$\quad$ crude protein & \\
Lys & 165 \\
Met & 7.6 \\
Ca & 3.7 \\
total P & 36.0 \\
MJ/kg ${ }^{2}$ & 6.8 \\
\hline
\end{tabular}

${ }^{1}$ Lutamix BASF, supplied per kg diet: vit. A 10000 i.u.; $\mathrm{D}_{3} 2000$ i.u.; mg: vit. E 15; vit. $\mathrm{K}_{3} 2$; vit. $\mathrm{B}_{1} 1$; vit. $\mathrm{B}_{2} 4$; vit. $\mathrm{B}_{6} 1,5$; vit. $\mathrm{B}_{12} 0.01$; Ca-pantotenate 8 ; niacine 25 ; folic acid 0.5 ; choline-Cl 250; Mn 100; Zn 50; Fe 50; Cu 8; J 8; Se 0.2 and Co 0.2

${ }^{2}$ calculated according to European Table (1989) as a sum of ME content of diet components

TABLE 2

Scheme of the experiment

\begin{tabular}{ccc}
\hline \multirow{2}{*}{ Group } & \multicolumn{2}{c}{ Form of limestone } \\
No. & fine (LF) & grit (LG) \\
\cline { 2 - 3 } & $\phi 0.1-0.4 \mathrm{~mm}$ & $\phi 2-4 \mathrm{~mm}$ \\
\hline I & 100 & 0 \\
II & 90 & 10 \\
III & 80 & 20 \\
IV & 60 & 40 \\
V & 50 & 50 \\
VI & 40 & 60 \\
VII & 20 & 80 \\
VIII & 10 & 90 \\
IX & 0 & 100 \\
X & & $100 \%$ of oyster shells \\
\hline
\end{tabular}


bones were prepared and breaking strength was estimated on a $5 \mathrm{~cm}$ distance metal bearer using an Instron 5542 .

The chemical composition of feed components and basal diet (dry matter, crude protein, crude fibre, crude ash, ether extract) was analysed according to AOAC (1990) methods. The metabolizable energy content of the basal diet was evaluated by adding the ME value of individual feeds, calculated using the content of basic nutrients and calculation factors according to European Table (1989). At the end of the experiment the calcium content of eggshells was estimated. The basal diet and washed (air-dried) shells were mineralized (AOAC, 1990) and the solution analysed using a Philips PU 9100 atomic absorption spectrometer. The phosphorus content in the basal diet was analysed by a colorimetric method (AOAC, 1990). Lysine and methionine in acid hydrolysates, methionine after preoxidation to methionine sulphone, were estimated in a colour reaction with ninhydrin reagent, using a Beckman-System Gold 126 AA automatic analyser.

Data were subjected to statistical analysis using one-way factorial analysis of variance. The significance of differences between means was determined by Duncan's multiple range test (using the Statistica 5.0 PL software package).

\section{RESULTS}

The average daily feed intake per hen in the experiment was $111 \mathrm{~g}$ and feed conversion ratio, $2.08 \mathrm{~kg} \cdot \mathrm{kg}^{-1}$ eggs or 125.5 per egg. Substitution of $100 \% \mathrm{LG}$ for LF increased feed intake and decreased laying performance and feed conversion for egg production $(\mathrm{P}<0.05)$ as compared with the control group or groups fed diets with moderate substitution of LG for a portion LF (Table 3). Sieve analysis of feed refusals (Table 4) showed an increase in the percentage content of particle fractions $>2 \mathrm{~mm}$ in groups fed diets with a higher LG:LF substitution rate, while the 1.5 to $2 \mathrm{~mm}$ fraction was not changed. The contribution of particles $<1.5 \mathrm{~mm}$ decreased in parallel.

The percentage, thickness and density of eggshells were not modified by the source of calcium used in the diet (Table 5). A significant increase of thickness was only observed at 33 weeks of age in eggshells from hens provided with 60 and $80 \% \mathrm{LG}$ as compared with the $100 \% \mathrm{LF}$ control group and $40 \% \mathrm{LG}$ or $100 \%$ oyster shells as a dietary calcium supplement $(\mathrm{P}<0.05)$.

The highest $\mathrm{Ca}$ content (\%) in shells (Table 6) was found in eggs from hens fed 50 and $60 \%$ LG replacement of LF and the lowest at $100 \%$ oyster shells or LG in the diet $(\mathrm{P}<0.05)$. The differences were also significant compared with groups receiving 20,40 and $80 \% \mathrm{LG}$ replacement $(\mathrm{P}<0.05)$. The total Ca content in shells was the highest at 20,50 and $60 \% \mathrm{LG}$ replacement $(\mathrm{P}<0.05)$. Hens supplied with 20,50 and $60 \%$ LG also deposited more $\mathrm{Ca}$ in eggs daily. 
TABLE 3

Average production results, $25-72$ weeks of age

\begin{tabular}{cccccc}
\hline $\begin{array}{c}\text { Group } \\
\text { No. }\end{array}$ & $\begin{array}{c}\text { Laying } \\
\text { rate } \\
\%\end{array}$ & $\begin{array}{c}\text { Egg } \\
\text { weight } \\
\mathrm{g}\end{array}$ & $\begin{array}{c}\text { Daily feed } \\
\text { intake } \\
\text { g hen }\end{array}$ & $\begin{array}{c}\text { Feed conversion } \\
\mathrm{g} \cdot \mathrm{l} \mathrm{egg}\end{array}$ & $\begin{array}{c}\text { Feed conversion } \\
\mathrm{kg} \cdot 1 \mathrm{~kg} \text { eggs }\end{array}$ \\
\hline I & $90.1^{\mathrm{a}}$ & 60.3 & $112.7^{\mathrm{ab}}$ & $124.7^{\mathrm{a}}$ & $2.07^{\mathrm{a}}$ \\
II & $89.9^{\mathrm{a}}$ & 60.6 & $112.3^{\mathrm{bc}}$ & $125.0^{\mathrm{a}}$ & $2.07^{\mathrm{a}}$ \\
III & $90.2^{\mathrm{a}}$ & 60.9 & $111.3^{\mathrm{ab}}$ & $125.0^{\mathrm{a}}$ & $2.07^{\mathrm{a}}$ \\
IV & $90.8^{\mathrm{a}}$ & 59.4 & $111.7^{\mathrm{ab}}$ & $123.7^{\mathrm{a}}$ & $2.09^{\mathrm{ab}}$ \\
V & $91.8^{\mathrm{a}}$ & 60.5 & $113.3^{\mathrm{bc}}$ & $124.7^{\mathrm{a}}$ & $2.07^{\mathrm{a}}$ \\
VI & $90.7^{\mathrm{a}}$ & 60.4 & $111.0^{\mathrm{ab}}$ & $122.3^{\mathrm{a}}$ & $2.02^{\mathrm{a}}$ \\
VII & $88.7^{\mathrm{a}}$ & 60.1 & $109.0^{\mathrm{a}}$ & $123.0^{\mathrm{a}}$ & $2.05^{\mathrm{a}}$ \\
VIII & $88.7^{\mathrm{a}}$ & 60.1 & $109.0^{\mathrm{a}}$ & $123.0^{\mathrm{a}}$ & $2.05^{\mathrm{a}}$ \\
IX & $84.9^{\mathrm{b}}$ & 62.8 & $114.8^{\mathrm{c}}$ & $135.3^{\mathrm{b}}$ & $2.18^{\mathrm{b}}$ \\
X & $88.1^{\mathrm{ab}}$ & 61.1 & $112.3^{\mathrm{bc}}$ & $128.0^{\mathrm{a}}$ & $2.11^{\mathrm{ab}}$ \\
SEM & 0.443 & 0.276 & 0.376 & 0.846 & $0.0117^{\mathrm{a}}$ \\
\hline
\end{tabular}

a.b.c - values in columns with different letters differ significantly at $P \leq 0.05$

TABLE 4

Particle size of limestone in feed refusals, in \% of total

\begin{tabular}{rccc}
\hline \multirow{2}{*}{$\begin{array}{c}\text { Proup } \\
\text { No. }\end{array}$} & \multicolumn{3}{c}{ Particle size, mm } \\
\cline { 2 - 4 } I & 1.5 & $1.5-2.0$ & $>2.0$ \\
II & 94.0 & 4.4 & 1.6 \\
III & 96.8 & 2.3 & 0.9 \\
IV & 92.5 & 5.1 & 2.4 \\
V & 94.9 & 3.7 & 1.4 \\
VI & 89.4 & 6.0 & 4.6 \\
VII & 85.6 & 3.0 & 11.4 \\
VIII & 68.9 & 4.1 & 27.0 \\
IX & 76.4 & 3.9 & 19.7 \\
X & 57.2 & 3.7 & 39.1 \\
\hline
\end{tabular}

${ }^{1}$ content LG - without feed rests

Eggs from control hens fed LF had a lower shell breaking strength than those from hens fed LG, as determined on 7 fixed dates (Table 7) and on average for the entire laying period. For the overall period of the experiment, the differences in hens supplied with $20-100 \%$ LG and $100 \%$ oyster shells were statistically confirmed $(\mathrm{P}<0.05)$. The highest breaking strengths were found in eggs from hens fed diets supplied with $40-60 \%$ LG. 


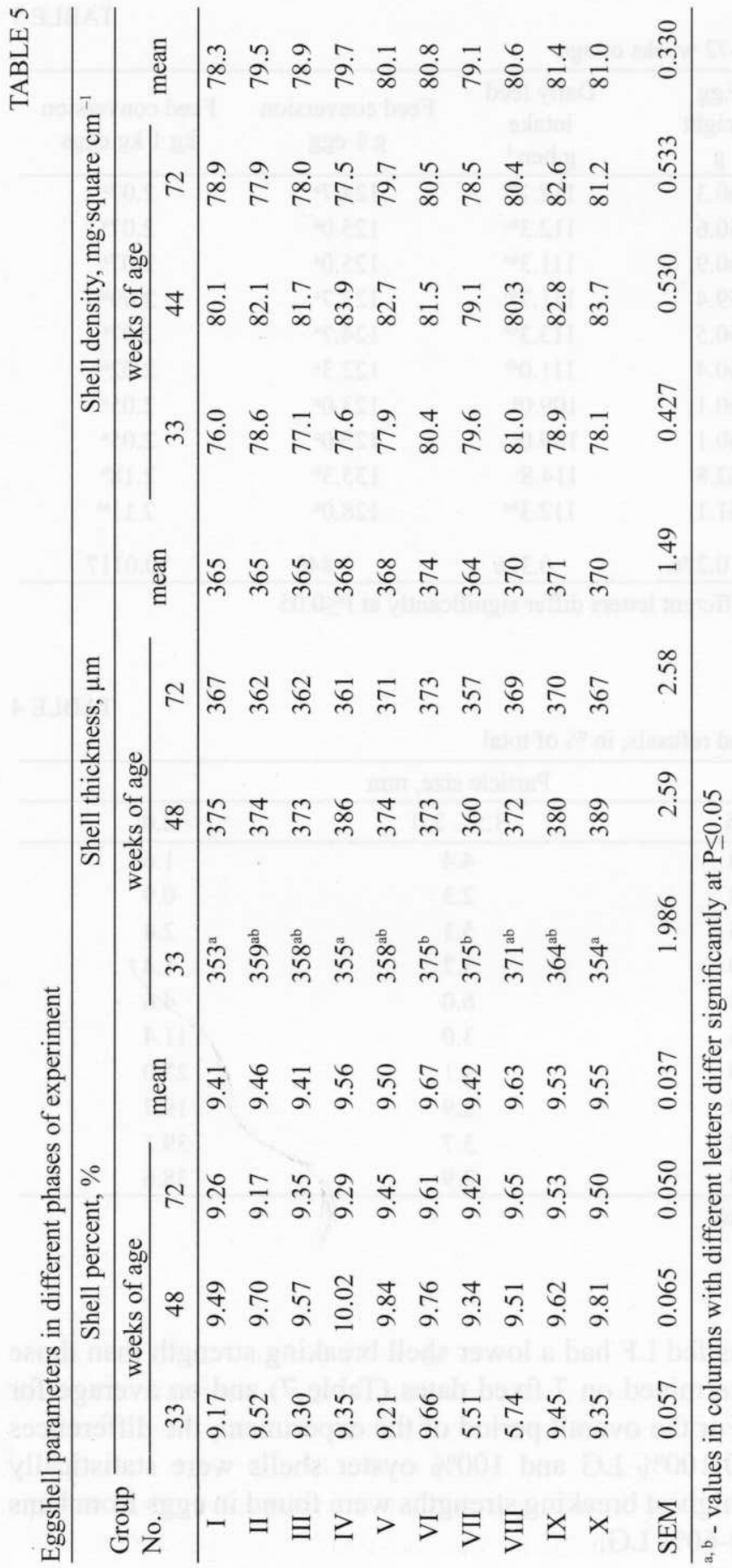


TABLE 6

Calcium content in eggshells

\begin{tabular}{cccc}
\hline $\begin{array}{c}\text { Group } \\
\text { No. }\end{array}$ & $\begin{array}{c}\text { Average Ca content } \\
\text { in eggshells } \\
\%\end{array}$ & $\begin{array}{c}\text { Total amount of Ca } \\
\text { in one eggshell } \\
\text { o }\end{array}$ & $\begin{array}{c}\text { Amount of Ca daily } \\
\text { deposited in eggshells } \\
\text { g }\end{array}$ \\
\hline I & $36.20^{\text {ab }}$ & $2.03^{\mathrm{a}}$ & $1.83^{\mathrm{a}}$ \\
II & $36.68^{\mathrm{abc}}$ & $2.19^{\mathrm{b}}$ & $1.97^{\mathrm{abc}}$ \\
III & $37.20^{\mathrm{cd}}$ & $2.30^{\mathrm{bc}}$ & $2.08^{\mathrm{cd}}$ \\
IV & $36.98^{\mathrm{bcd}}$ & $2.20^{\mathrm{b}}$ & $2.00^{\mathrm{bc}}$ \\
V & $38.42^{\mathrm{e}}$ & $2.41^{\mathrm{c}}$ & $2.21^{\mathrm{d}}$ \\
VI & $37.78^{\mathrm{de}}$ & $2.27^{\mathrm{bc}}$ & $2.06^{\mathrm{cd}}$ \\
VII & $37.24^{\mathrm{cd}}$ & $2.21^{\mathrm{b}}$ & $1.96^{\mathrm{abc}}$ \\
VIII & $36.58^{\mathrm{abc}}$ & $2.21^{\mathrm{b}}$ & $1.96^{\mathrm{abc}}$ \\
IX & $36.65^{\mathrm{abc}}$ & $2.21^{\mathrm{b}}$ & $1.88^{\mathrm{ab}}$ \\
X & $36.03^{\mathrm{a}}$ & $2.23^{\mathrm{b}}$ & $1.97^{\mathrm{abc}}$ \\
SEM & & & \\
\hline
\end{tabular}

$\mathrm{a}, \mathrm{b}, \mathrm{c}, \mathrm{d}, \mathrm{e}$ - values in columns with different letters differ significantly at $\mathrm{P} \leq 0.05$

TABLE 7

Eggshell breaking strength $(\mathrm{N})$ in different phases of experiment

\begin{tabular}{|c|c|c|c|c|c|c|c|c|}
\hline \multirow{2}{*}{$\begin{array}{l}\text { Group } \\
\text { No. }\end{array}$} & \multicolumn{7}{|c|}{ Weeks of age } & \multirow{2}{*}{$\begin{array}{c}\text { Overall } \\
\text { mean }\end{array}$} \\
\hline & 33 & 48 & 53 & 58 & 62 & 68 & 72 & \\
\hline I & $38.0^{\mathrm{a}}$ & $33.8^{\mathrm{a}}$ & $33.2^{\mathrm{a}}$ & 35.6 & $32.6^{a}$ & $33.0^{\mathrm{ab}}$ & $28.9^{\mathrm{a}}$ & $33.6^{\mathrm{a}}$ \\
\hline II & $40.5^{\mathrm{abc}}$ & $34.4^{\mathrm{a}}$ & $35.9^{\mathrm{ab}}$ & 34.0 & $35.1^{\mathrm{ab}}$ & $32.5^{\mathrm{ab}}$ & $29.4^{\mathrm{a}}$ & $34.5^{\mathrm{ab}}$ \\
\hline III & $39.7^{a b c}$ & $35.1^{\mathrm{ab}}$ & $37.9^{\mathrm{bc}}$ & 33.8 & $35.0^{\mathrm{ab}}$ & $32.2^{\mathrm{a}}$ & $34.2^{\mathrm{b}}$ & $35.4^{\mathrm{bc}}$ \\
\hline IV & $41.3^{\mathrm{bcd}}$ & $36.1^{\mathrm{abc}}$ & $40.7^{\mathrm{c}}$ & 36.2 & $40.0^{c}$ & $36.9^{c}$ & $34.7^{b}$ & $38.0^{\mathrm{d}}$ \\
\hline V & $42.3^{\mathrm{cd}}$ & $38.8^{\text {cd }}$ & $35.1^{\text {ab }}$ & 36.1 & $37.7^{\mathrm{bc}}$ & $34.8^{\mathrm{abc}}$ & $34.2^{b}$ & $37.0^{\text {cd }}$ \\
\hline VI & $43.5^{\mathrm{d}}$ & $39.7^{\mathrm{d}}$ & $39.4^{c}$ & 36.8 & $39.3^{\mathrm{bc}}$ & $34.5^{\mathrm{abc}}$ & $35.0^{\mathrm{b}}$ & $38.2^{\mathrm{d}}$ \\
\hline VII & $40.3^{\mathrm{abc}}$ & $37.0^{\text {abed }}$ & $36.1^{\mathrm{ab}}$ & 35.8 & $36.4^{\mathrm{abc}}$ & $38.2^{\mathrm{c}}$ & $35.1^{\mathrm{b}}$ & $36.9^{\mathrm{cd}}$ \\
\hline VIII & $39.3^{\mathrm{ab}}$ & $38.1^{\text {bod }}$ & $35.9^{\mathrm{ab}}$ & 34.7 & $37.5^{\mathrm{bc}}$ & $37.0^{c}$ & $31.9^{\mathrm{ab}}$ & $36.3^{c}$ \\
\hline IX & $41.0^{\mathrm{abcd}}$ & $36.7^{\text {abcd }}$ & $34.2^{\mathrm{a}}$ & 35.6 & $35.6^{\mathrm{ab}}$ & $34.5^{\mathrm{abc}}$ & $33.5^{\mathrm{b}}$ & $35.9^{\mathrm{bc}}$ \\
\hline $\mathrm{X}$ & $40.4^{\mathrm{abc}}$ & $36.3^{\mathrm{abc}}$ & $35.8^{\mathrm{ab}}$ & 34.5 & $35.7^{\mathrm{ab}}$ & $36.0^{\mathrm{bc}}$ & $34.0^{\mathrm{b}}$ & $36.1^{\mathrm{bc}}$ \\
\hline SEM & 0.290 & 0.346 & 0.375 & 0.385 & 0.443 & 0.387 & 0.452 & 0.192 \\
\hline
\end{tabular}

a,b,c,d - values in columns with different letters differ significantly at $\mathrm{P} \leq 0.05$

Tibia breaking strength was positively modified by LG supplementation, but only at $20 \%$ LG replacement of LF was the effect statistically confirmed $(\mathrm{P}<0.05)$ as compared with the control $100 \%$ LF diet (Table 8).

In eggs collected at 33, 48 and 72 weeks of age (Table 8) the degree of yolk pigmentation in the $100 \mathrm{LF}$ control group was on average lower than in eggs from hens fed diets supplied with $20-50$ and $80-100 \%$ LG and $100 \%$ oyster 
shells $(\mathrm{P}<0.05)$. The positive effect of grit on egg yolk pigmentation was marked, especially in eggs collected at 48 weeks of age.

TABLE 8

Tibia breaking strength and yolk colour

\begin{tabular}{|c|c|c|c|c|c|}
\hline \multirow{3}{*}{$\begin{array}{l}\text { Group } \\
\text { No. }\end{array}$} & \multirow{3}{*}{$\begin{array}{c}\text { Tibia breaking } \\
\text { strength } \\
\mathrm{N}\end{array}$} & \multicolumn{4}{|c|}{ Yolk colour (points in Roche scale) } \\
\hline & & \multicolumn{4}{|c|}{ weeks of age } \\
\hline & & 33 & 48 & 72 & mean \\
\hline I & $154^{\mathrm{a}}$ & $6.00^{\mathrm{ab}}$ & $7.55^{\mathrm{a}}$ & $7.78^{\mathrm{abc}}$ & $7.11^{\mathrm{a}}$ \\
\hline II & $195^{\mathrm{ab}}$ & $6.44^{\text {bed }}$ & $7.89^{\mathrm{ab}}$ & $8.22^{\text {bed }}$ & $7.52^{\mathrm{ab}}$ \\
\hline III & $217^{\mathrm{b}}$ & $7.11^{\text {def }}$ & $7.89^{\mathrm{ab}}$ & $8.41^{\mathrm{cd}}$ & $7.81^{\text {bed }}$ \\
\hline IV & $181^{\mathrm{ab}}$ & $7.55^{\mathrm{f}}$ & $8.78^{\mathrm{c}}$ & $8.55^{\mathrm{cd}}$ & $8.30^{\text {de }}$ \\
\hline V & $199^{\mathrm{ab}}$ & $7.44^{\mathrm{ef}}$ & $9.11^{\mathrm{cd}}$ & $9.00^{\mathrm{d}}$ & $8.52^{\mathrm{e}}$ \\
\hline VI & $190^{\mathrm{ab}}$ & $5.55^{\mathrm{a}}$ & $9.44^{\text {cde }}$ & $7.22^{\mathrm{a}}$ & $7.41^{\mathrm{ab}}$ \\
\hline VII & $182^{\mathrm{ab}}$ & $6.11^{\mathrm{abc}}$ & $9.67^{\mathrm{de}}$ & $7.44^{\mathrm{ab}}$ & $7.74^{\mathrm{bc}}$ \\
\hline VIII & $173^{\mathrm{ab}}$ & $6.33^{\mathrm{bc}}$ & $9.67^{\mathrm{de}}$ & $7.67^{\mathrm{abc}}$ & $7.89^{\mathrm{bcd}}$ \\
\hline IX & $190^{\mathrm{ab}}$ & $7.00^{\mathrm{def}}$ & $10.00^{e}$ & $7.78^{\mathrm{abc}}$ & $8.26^{\mathrm{de}}$ \\
\hline $\mathrm{X}$ & $171^{\mathrm{ab}}$ & $6.78^{\text {cde }}$ & $10.11^{\mathrm{e}}$ & $7.78^{\mathrm{abc}}$ & $8.22^{\text {cde }}$ \\
\hline SEM & 4.875 & 0.094 & 0.123 & 0.099 & 0.067 \\
\hline
\end{tabular}

a, b,c, d, e, $\mathrm{f}$ - values in columns with different letters differ significantly at $\mathrm{P} \leq 0.05$

\section{DISCUSSION}

In this experiment, total substitution of LG for LF limestone in the diet negatively affected laying performance and feed conversion per egg basis but not the average mass of laid eggs. At a lower level of LG supplementation the effects were not statistically significant. This finding confirms in part previous reports on the effect of limestone and oyster shell particle size on laying performance (Roland and Harms, 1973; Roland, 1986; Guinotte and Nys, 1991), and on feed intake and egg mass data reported by Vogt (1983).

Analysis of feed refusals shows the presence of LG remainders of 0.95 to $4.61 \%$ from diets supplied with $10-50 \%$ LG. Starting from $60 \%$ LG in the diet, the amounts of refused LG in feeders increased to $11.45 \%$ and grew markedly to $39.1 \%$ in the diet supplied with $100 \%$ LG. This may indicate a limit value for voluntary intake of grit particles between $60-80 \%$ and is equal to $5.5 \mathrm{~g}$ of daily limestone grit (2-4 mm) consumption per hen.

Particles of calcium carbonate in the diet increased the thickness of eggshells only at 33 weeks of age and at $60-80 \%$ limestone supplementation. This finding confirms the report of Krasucki et al. (2002) for the period of peak egg production in hens. In other cases the percentage, thickness and density of eggshells were not modified by LG. 
Complete replacement of LF by oyster shells or LG decreased the percentage of $\mathrm{Ca}$ in eggshells to a level similar as in the control-LF group. The values were lower compared with groups in which LG replaced part of LF $(20-80 \%)$. The amounts of calcium deposited daily in eggshells were higher at a moderate level of LG substitution than at a higher level or in the control LF group. This may suggest better $\mathrm{Ca}$ utilization in hens fed diets with partial substitution of LG for LF. A significant increase of Ca deposition in eggs was reported by Abdallah et al. (1993) using higher Ca levels in the diet.

Substitution of LG for LF limestone in the diet affected eggshell and tibia bone breaking strength. In the present study the average eggshell breaking strength for all laying periods showed significantly better values at partial (20-90\%) or $100 \%$ LG or oyster shell substitution as compared with the groups fed the diet with LF or only $10 \%$ LG. The highest values were found at $40-60 \%$ LG replacement, when hens received diets containing limestone grit at levels of 3.24-4.86 g·100g-1. These results are generally consistent with numerous reports confirming a positive effect of coarse particle sized limestone on eggshell quality (Scott et al., 1971; Guinotte and Nys, 1991; Richter et al., 1999), mainly in the summer (Roland and Harms, 1973), but are inconsistent with other results reported in the review by Roland (1986). The inconsistencies in the positive effect of limestone may depend not only on particle size but also on the lighting schedules used, especially the duration of the dark period.

Coarse particles of limestone improved tibia bone breaking strength but only at a $20 \%$ level of LG. These results are similar to other publications (Guinotte and Nys, 1991) and in part to Cheng and Coon (1990).

The degree of egg yolk pigmentation assessed at 33 and 48 weeks of age improved under the influence of limestone grit in the diet. This effect disappeared at 68 weeks of age. These results can be compared with the positive effect of large particle size calcium source on nitrogen retention and energy utilization (Tortuero and Centeno, 1973). It is not unlikely that the presence of large particles in the gizzard caused better destruction of feed cells and more efficient liberation of xanthophylls. In the period of high laying production this effect could have been more strongly marked as an effect of a greater xanthophyll pool in the birds' bodies.

The effect of LG and oyster shell at $100 \%$ substitution for limestone meal on performance, eggshell and bone quality was generally similar and confirms the findings of Hamilton et al. (1985).

\section{CONCLUSIONS}

The present research may suggest that the limit value for voluntary intake of limestone grit (LG) is $5.5 \mathrm{~g}$ daily per hen. Particulate limestone $(2-4 \mathrm{~mm}, \mathrm{LG})$ introduced to the diet in place of the fine form (LF) increased eggshell thickness 
in the first part of the laying period (60-80\% LG substitution level), improved yolk pigmentation (20-100\% LG), and increased calcium deposition in eggshells (10$100 \% \mathrm{LG})$. Eggshell breaking strength was similarly increased $(20-100 \% \mathrm{LG})$, but an improvement of tibia bone strength was observed only at the $20 \%$ level of LG substitution.

\section{ACKNOWLEDGMENTS}

The authors would like to thank the Limestone Mine Ltd. Czatkowice (Krzeszowice, Poland) for supplying the two limestone forms and the Central Laboratory IZ in Kraków-Balice for analytical services.

\section{REFERENCES}

Abdallah A.G., Harms R.H., El-Husseiny O., 1993. Performance of hens laying eggs with heavy or light shell weight when fed diets with different calcium and phosphorus levels. Poultry Sci. 72, 1881-1891

AOAC, 1990. Official Methods of Analysis, Association of Official Analytical Chemists. $15^{\text {th }}$ Edition. Arlington, VA

Cheng T.K., Coon C.N., 1990. Effect of layer performance and shell quality of switching limestone with different solubilities. Poultry Sci. 69, 2199-2203

European Table of Energy Values for Poultry Feedstuffs, 1989. WPSA, Wageningen

Farmer M., Roland D.A., Clark A.J., 1986. Influence of dietary calcium on bone calcium utilization. Poultry Sci. $65,337-344$

Guinotte F., Nys Y., 1991. Effects of particle size and origin of calcium sources on eggshell quality and bone mineralisation in laying hens. Poultry Sci. 70, 583-592

Hamilton R.M.G, Fairfull R.W., Gowe R.S., 1985. Use of particulate limestone or oyster shell in the dietary regimen of White Leghorn hens. Poultry Sci. 64, 1750-1762

Krasucki W., Witkowski A., Szafran K., 2002. Laying and egg quality traits in hens in relation to the food calcium source and form (in Polish). Ann. UMCS, Sect. EE, 20, 54, 379-386

Richter G., Kiessling G., Ochrimenko W.I., Ludke H., 1999. Einfluss der Partikelgrosse und der Calciumquelle auf die In-vitro-Loslichkeit des Calciums, die Leistungen und die Eischalenqualität bei Legehennen. Arch. Geflügelk. 63, 208-213

Roland D.A., 1986. Eggshell quality IV. Oyster shells versus limestone and the importance of particle size or solubility of Ca source. World Poultry Sci. J. 42, 166-171

Roland D.A., Harms R.H., 1973. Effect of various sources and sizes of calcium carbonate on shell quality. Poultry Sci. 52, 369-372

Scott M.L., Hull S.J., Mullenhoff P.A., 1971. The calcium requirements of laying hens and effects of dietary oyster shell upon egg shell quality. Poultry Sci. 50, 1055-1063

Tortuero F., Centeno C., 1973. Studies of the use of calcium carbonate in the feeding of laying hens during summer months. Poultry Sci. 52, 866-872

Vogt H., 1983. Die Eischalenstabilität und ihre Abhängigkeit von Herkunft and Korngröße des Calciumfuttermittels. Arch. Geflügelk. 47, 20-25 


\section{STRESZCZENIE}

\section{Wapień w formie miałkiej kredy lub żwirku w żywieniu kur nieśnych - wpływ na produkcyjność} oraz jakość skorupy jaj i kości

Skałę wapienną o stopniu czystości spełniającym wymagania paszowe rozdrobniono na cząstki o średnicy 0,1-0,4 mm (kreda paszowa - LF) lub LF zastępowano żwirkiem (LG) o średnicy 2-4 mm. Do doświadczenia wzięto 180 kur niosek Hy-Line Brown utrzymywanych w indywidualnych klatkach, podzielonych na 10 grup po 18 . Diety I i X zawierały $8,1 \%$ LF lub muszli ostryg, w pozostałych dietach 10, 20, 40, 50, 60, 80 i 100\% LF zastępowano LG.

Zamiana kredy żwirkiem wapiennym w mieszance paszowej dla niosek spowodowała wzrost grubości skorupy jaja (przy 60-80\% LG) w pierwszym okresie nieśności, odłożenia wapnia w skorupie (10-100 \% LG) oraz wpływała na zwiększenie intensywności zabarwienia żółtka jaja (20-100\% LG), a także na zwiększenie odporności skorupy jaja na zgniecenie $(20-100 \%$ LG). Istotny wzrost odporności kości udowej na złamanie stwierdzono tylko po wprowadzeniu $20 \%$ LG. Analiza nie zjedzonej paszy wskazuje, że dobrowolne, dzienne pobranie żwirku wapiennego przez kurę wynosi około $5,5 \mathrm{~g}$. 